\title{
The Complexity of Policy Mirroring: The Connection between International and Slovenian Higher Education Policy Discourse
}

JANJA KoMLJENOVIČ ${ }^{1}$

$\approx$ The contemporary economic imaginary of the 'knowledge-based economy' is changing the perception of higher education in Europe. The goals of higher education are changing and reform of institutions is predicted. The present article examines these reforms and conceptualisations of higher education by presenting the results of discourse analysis of 47 international policy documents at the European level and two comprehensive national strategies of the Republic of Slovenia for higher education, research and innovation. Based on the analysis of the European documents, the article suggests that two main discourses are constructed: a) 'the research-based society and economy', and b) 'reforming the university. These present the emergence of a new idea of higher education at the international and national levels. The article investigates the extent to which these discourses are present in Slovenian higher education policy. The findings show that Slovenian discourse hesitates to embrace them fully. In particular, the idea of the managerial university is marginal in Slovenian discourse.

Keywords: higher education policy, discursive analysis, supranational policy making, the knowledge economy, Slovenian higher education

1 University of Ljubljana and Centre for Educational Policy Studies, Faculty of Education, University of Ljubljana janja.komljenovic@guest.arnes.si 


\section{Kompleksnost prenosa diskurzov v politike: povezava mednarodnih in slovenskih diskurzov visokošolskih politik}

JANJA KoMLJENOVIČ

$\propto$ Zdajšnji ekonomski imaginarij »ekonomije, ki temelji na znanju«, spreminja percepcijo visokega šolstva v Evropi. Spreminjajo se cilji visokega šolstva in napovedujejo se reforme institucij. V prispevku so analizirane te reforme in konceptualizacija visokega šolstva, tako da predstavimo izsledke diskurzivne analize 47 mednarodnih političnih dokumentov na evropski ravni in dveh celovitih visokošolskih, raziskovalnih in inovacijskih strategij. Na osnovi analize evropskih dokumentov članek nakaže, da sta izoblikovana dva glavna diskurza: a) »družba in ekonomija, ki temeljita na raziskovanju«, in b) »reformiranje univerze«. Diskurza predstavljata pojav nove ideje visokega šolstva na mednarodnih in nacionalnih ravneh. Članek preverja obseg, v katerem sta diskurza prisotna v slovenskih visokošolskih politikah. Izsledki kažejo, da je slovenski diskurz zadržan do tega, da bi ju popolnoma sprejel. Še zlasti ideja menedžerske univerze je v slovenskem diskurzu marginalna.

Ključne besede: visokošolske politike, diskurzivna analiza, nadnacionalno oblikovanje politik, ekonomija znanja, slovensko visoko šolstvo 


\section{Introduction}

The emerged cultural political economy (Jessop, 2008) in Europe, which paves the way to the growing importance of supranational decision making, offers a new meaning of higher education (HE). European policy and decisions directly affect higher education institutions (HEIs). Divided between different roles such as cultural versus economic, utilitarian versus non-utilitarian (Gornitzka, 2010), HEIs are expected to reform. For a European Union (EU) member state, the Bologna Process (BP) and the EU are the two most important international arenas for $\mathrm{HE}$ coordination. The EU has gained in importance in the past decade with regard to influencing member states' national HE policy, especially via the Lisbon Strategy and by using new modes of governance (such as the open method of coordination) and new institutionalised governance structures (such as expert groups or 'clusters' on E\&T2010) (Corbett, 2011). Thus states are expected to follow the EU course, despite the unchanged legal basis of retaining formal competence over $\mathrm{HE}$.

The article aims to identify the discourses of four clusters of international policy documents relevant to the European higher education area (EHEA) considering the horizontal dynamics of policy making (Gornitzka, 2010). It focuses on the new meaning of HE and the expected roles of HEIs. Using a case study approach, the extent to which these discourses are present in Slovenian HE policy is then demonstrated.

\section{Approach and methods}

Four clusters of international policy documents significant to European $\mathrm{HE}$ are analysed, i.e., documents of the EU, the BP, the European University Association (EUA) and the Council of Europe (CoE). For the analysis, 47 official documents relevant to $\mathrm{HE}$ and released since 1998 were chosen (Table 1). With regard to Slovenia, the analysis focused on two national strategies, i.e., the Resolution on Research and Innovation Strategy of Slovenia 2011-2020 (RISS) and the Resolution on the National Higher Education Programme 2011-2020 (NHEP) (Kolar \& Komljenovič, 2011), both of which were adopted by the National Assembly of the Republic of Slovenia in May of 2011. Together, they present the overarching and comprehensive strategies for HE, research and innovation that should be followed by the regulatory framework, HEIs and other actors. 
Table 1. The type and number of international policy documents included in the analysis.

\begin{tabular}{|l|l|l|}
\hline \multirow{4}{*}{ Council of the EU } & Type of document & Number of documents \\
\hline & Resolution & 2 \\
\cline { 2 - 3 } & Recommendation & 1 \\
\cline { 2 - 3 } & Conclusion & 3 \\
\hline \multirow{2}{*}{ European Commission All } & Communication & 7 \\
\cline { 2 - 3 } & Report & 4 \\
\hline \multirow{2}{*}{ BP } & & 17 between 2001 and 2011 \\
\hline BP All & Declaration & 3 \\
\cline { 2 - 3 } EUA & Communiqué & 6 \\
\hline \multirow{3}{*}{ CoE } & & 9 between 1998 and 2012 \\
\hline \multirow{2}{*}{ CoE All } & Declaration & 6 between 2001 and 2011 \\
\hline All & $\begin{array}{l}\text { Parliamentary Assembly } \\
\text { Recommendation }\end{array}$ & 2 \\
\cline { 2 - 3 } & $\begin{array}{l}\text { Committee of Ministers } \\
\text { Recommendation }\end{array}$ & 13 \\
\hline & & 15 between 1998 and 2012 \\
\hline
\end{tabular}

The analysis of the international documents was undertaken in three phases. In the first phase, all of the policy documents were reviewed in order to develop a general understanding of the context. In the second phase, the policy documents were coded using NVIVO computer software, which allowed the ideas with a similar message or content to be grouped. In the third phase, the groups of ideas were discursively analysed using the analytical framework of discursive institutionalism (Schmidt, 2010) and two discourses were constructed. The horizontal perspective of European policy making (Gornitzka, 2010) was most convenient to connect the EU cluster with the Lisbon Strategy and to integrate the four clusters of documents.

For the analysis of national documents, the first two phases were the same as those described above. The extent to which international discourses are mirrored in national policy was then analysed.

The theoretical framework of cultural political economy (Jessop, 2008) was used, as well as the concepts of semiosis, political rationale, policy and economic imaginaries (Jessop, 2008; Robertson, 2008). The discourses are constructed such that all of the ideas from the four clusters of policy documents are gathered together. This means that not all of the presented ideas that construct the discourses in the present paper are actively promoted by all of the clusters. The differences between the clusters in the discourses are only mentioned where there are specific points of contradiction. 
For a precise presentation of the European discourses it would be important to show how and where ideas are generated and developed in the policy documents, how they travel in time and between clusters, the differences between clusters, and similar. However, the scope of the present study is not broad enough, and the aim was therefore to show the connection between the constructed European discourses and Slovenian policy.

\section{The context}

Higher education has been subject to substantial changes in the past two decades (Blasi, 2002; Weert \& Vucht Tijssen, 1999), e.g., massification, globalisation, scientific and technological development, internationalisation, increased mobility, and stronger demands for quality and supranational decision making (e.g., Bladh, 2007; Wende, Beerkens, \& Teichler, 1999). Furthermore, a specific market has been created for HE (Boer, Enders, \& Jongbloed, 2009). In times of neoliberalism, markets have become a technology that is used for controlling the public sector and increasing its effectiveness (Olssen \& Peters, 2005). The emergence of the knowledge economy (KE), in which knowledge, research and innovation play the central role, challenges the traditional role of the university (Felt, 2005; Välimaa \& Hoffman, 2007). The KE, advanced as a social process integrating ideational, material, institutional and relational moments (Robertson, 2008), is gradually coming to represent the central strategy and discourse in modern Europe (Fairclough \& Wodak, 2008).

The concept of the KE derives from changes in industrial competitiveness and technological advance in the 1980s, when the leading global economies responded by encouraging talented people to acquire skills and generate innovative technologies to keep the economy strong. It is reflected in shifts from an economy based on low skills to one depending on knowledge, from a Fordist to a post-Fordist society, in advancing global competition and transnational decision making, as well as in the process of turning knowledge into capital (Jessop, 2008; Olssen \& Peters, 2005).

Analysing the aforementioned phenomena, Jessop (2008) presents the concept as the hegemonic economic imaginary - discursively constructed imagined economies. As such, it influences the organisation of societal sectors that have been exposed to a substantial ideational and representational shift, including HE (Robertson, 2008). This is reflected in profoundly new goals for HEIs (Gornitzka, 2010; Olssen \& Peters, 2005), conceptually transforming autonomy as a relationship between HEIs and society (Olsen, 2009), as well as leading to important changes, such as HE becoming an industry per se, providing skills 
and competences to customers, or to $\mathrm{HE}$ becoming largely subordinated to economic necessities (Jessop, 2008).

This section has briefly illustrated the context of HE in Europe, which is in line with the KE based on findings from the literature. The paper continues by outlining the major trends in the European HE policy of the four clusters. The findings will be synthesised using two discourses, i.e., 'the knowledgebased society and economy' and 'reforming the university', each of which encompasses three sub-discourses.

\section{International policy - findings}

\section{DISCOURSE 1 - The knowledge-based society and economy}

As a concept, 'the knowledge-based society and economy' has evidently become a discourse of the analysed policy documents. Firstly, the presence of this economic arrangement is not contested, but is rather taken as an indisputable fact, a finding confirmed by the literature (e.g., Nokkala, 2007; Miklavič, 2012). Secondly, the discourse in all of the clusters picks up the notion of HE being central to the economy. The literature explains that this was mainly done due to the Lisbon Strategy (Corbett, 2011; Gornitzka, 2010), which managed to position the role of $\mathrm{R} \& \mathrm{D}$ for economic competitiveness and growth, as well as to elaborate common priorities (Maassen \& Stensaker, 2011). Thirdly, the discourse communicates the fact that the KE demands more people with HE qualifications and, moreover, that graduates need the 'right mix of skills'. Fourthly, the discourse recognises increased competitiveness in all of the clusters, and there is agreement on the necessity of making Europe globally attractive. Fifthly, the discourse points out the increased demand for knowledge transfer from university to business and the rising demand for knowledge exploitation.

\section{New roles of universities}

The discursive purpose of the university has moved away from the classic goal of the general advancement of knowledge to the benefit of society. Instead, emphasis is placed on economic reasons, i.e., selling new knowledge (either by business or universities) and creating new jobs via spin-offs and start-ups. The function of teaching is to 'produce the human capital capable of adequately working in knowledge-intensive jobs'. However, the analysed policies do encompass the 'traditional' purposes of HE: the contribution to societal and cultural development, democracy and peace, social cohesion, active citizenship and individual growth. The CoE has highly elaborated reasoning 
emphasising this particular role of universities (e.g., Corbett, 2012). However, there are two main findings regarding the roles and goals of universities relevant to the present argument: firstly, these traditional purposes do not act as a substantively alternative rationale for the 'new' (i.e., economic) goals that are promoted by the KE. Secondly, they are often an addition to the concepts of the KE, as they have a positive connotation. Thus the European discourse predominantly reveals roles of HE that derive from the KE. Etzkowitz (1998) sees the emerging entrepreneurial university integrating economic development as a core function of university as being similar to the first academic revolution, when research was established as an academic function alongside teaching.

In addition, the scope of the role of universities is broadening, in the sense that they are no longer just foreseen to provide knowledge that should be disseminated by teaching and used by other actors; instead, universities are said to be "motors of the new, knowledge-based paradigm" (European Commission, 2005), to "increasingly become significant players in the economy" (European Commission, 2006), to be "crucial drivers of Europe's ambition to be the world's leading knowledge-based economy and society" (European Commission, 2009), and "motors for economic recovery" (EUA, 2009).

\section{New aims for the higher education system}

HEIs are foreseen to directly care for the economic prosperity and competitiveness of states and regions. The discourse establishes expectations that HE will help "Europe's standing in the world" (Sorbonne Declaration, 1998) and "European economic and political success" (European Commission, 2001), that it will ensure the success of the Lisbon Strategy and the Europe 2020 Strategy, and that it will enable Europe to achieve the goal of becoming a successful KE, for example:

Governments and other stakeholders need to acknowledge the extent of institutional innovation, and the crucial contribution universities do and must make to the European Research Area and the longer-term development of the European knowledge society as outlined in the Lisbon declaration of the European Union (EUA, 2003).

The reforms of the university (which are elaborated below in the second discourse) are predicted to be undertaken in order to increase the attractiveness of Europe.

\section{Supranational policy making}

The BP is by itself the most unprecedented regional platform for coordination to launch HE reforms in all of the participating counties. Furthermore, 
the EU has gained importance and informal competence for HE policy making mainly by making the BP part of the Lisbon Strategy (Corbett, 2011; Gornitzka, 2010), which was also supported by the EUA and the BP.

EU member states are now expected to achieve internationally set goals, prepare national reforms in line with the common European strategy, set national benchmarks based on European benchmarks, report on these annually to the European Commission, and similar. There are also measures for universities, i.e., they are expected to implement the Code of Conduct for the recruitment of researchers prepared at the European level, to attain quality labels and seals developed by European associations or bodies, to choose external quality assurance based on the listing in the European Quality Assurance Register for Higher Education (EQAR) rather than national criteria, and similar.

\section{DISCOURSE 2 - Reforming the University}

The discourse on reforming the university brings many ideas on how universities should change in line with findings of other authors presenting shifts of the system towards a 'new public management' concept (e.g., Olsen, 2009) or towards understanding HE as a business (e.g., Gumport, 2000; Jessop, 2008).

\section{Managerial university}

The sub-discourse on the managerial university encompasses ideas on reforming university governance structures, changing the concept of autonomy and the regulatory framework, and updating the quality assurance system and the funding arrangements.

The idea on the governance of universities in this sub-discourse is introduced by the EU as well as the EUA. The discourse predicts that governance will be professionalised and will introduce an institutional strategy setting. It is foreseen that top-level leadership and management with sufficient powers will be installed, that university leadership will be trained, and that preference will be given to people from outside the academic world taking over the leadership function. The world of business is to advise universities on the management change. In addition, there should be external representation in governance structures. Moreover, new internal governance structures should be developed in order to overcome internal fragmentation into disciplines, faculties and departments, and an interdisciplinary approach to research and teaching should be implemented. The CoE does not contradict these ideas, but simply adds principles of democratic governance. 
These reforms would be successful if the HE system were to change in line with a new kind of 'social contract', whereby the state is predicted to focus on the strategic orientation of the system as a whole and avoid micro-management and over-regulation. All four clusters support this idea, and the CoE specifies what should be left to governmental responsibility and what should be given to universities (e.g., Council of Europe, 2007, 2012). HEIs would thus be granted 'more' autonomy.

The concept of autonomy has a specific and contrasting meaning in the analysed documents. It is instrumentalised for many purposes, e.g., for universities to respond to societal needs and expectations, to contribute to European attractiveness and competitiveness, to improve the quality of $\mathrm{HE}$, to find new funding, and similar. In the EU ideation, autonomy is first understood as an obstacle and, next to guaranteed funding, as the reason why European universities have not been responsive to societal needs in the past decades (European Commission, 2003). This is assumed to have led to the contemporary problems in European HE (which are impressive in the EU ideation) and must change in future. Two years later, institutional autonomy is presented differently; not as an obstacle to change, but as "a pre-condition for universities to be able to respond to society's changing needs" (European Commission, 2005). This idea is put in the systemic context, indicating that national regulations are hampering universities' attempts to make the necessary changes, and in this document institutional autonomy is equated with national deregulation, an idea that has been subsequently kept alive in EU documents. In its Resolution, the Council of the EU (Council of the European Union, 2007) reaffirms the ideation of governance and instrumentalises autonomy with regard to funding. This is yet another idea concerning autonomy; a tool to increase funding from non-public sources, which is repeated thereafter. Additionally, autonomy is foreseen as attracting global talent and contributing to professional human resource management.

The EUA cluster promotes institutional autonomy for the same instrumental reasons, while adding other elements to the understanding of autonomy, i.e., autonomy as more than just deregulation or financial diversification. Based on the cognitive and normative classification of ideas (Schmidt, 2010), the ideas are classified as cognitive since they bring the rationale of achieving the aforementioned goals. However, the EUA cluster also includes normative ideas that position autonomy as a value in itself. The CoE focuses on the normative understanding of autonomy, and uses historical arguments and tradition to promote autonomy as a value necessary for democratic and humanistic societies. Although the EUA and the CoE include the normative view of university autonomy, they both move to its managerial conceptualisation. The EUA 
elaborates on how it understands autonomy and manages to present a precise illustration of this in the past two years by preparing an autonomy scorecard. It identifies four elements of autonomy: academic, financial, staffing and organisational. This has also been picked up by the $\mathrm{CoE}$ in its latest document (Council of Europe, 2012). The managerial side of the ideation of autonomy fits well into the economic imaginary, containing reforms in line with the New Public Management (Olsen, 2009).

System diversification is seen as contributing to the attractiveness and competitiveness of European HE; with regard to the EU cluster, HEIs need to differentiate in focusing on different groups of potential students, to provide a differentiated study offer and way of teaching. More importantly, each university is to find its own strength and focus on it, thus specialising in the identified fields. There would be a small number of renewed, excellent research universities and the rest. Not all universities are encouraged to do research anymore. The EUA cluster supports the part in which universities are predicted to find their strengths, focus on them and develop institutional research portfolios.

The funding of HE should increase significantly, more or less from the private sources, i.e., industry and students. It is suggested that the funding system move from basic funding to outcomes-based and competitive finding, with specific elements being rewarded, such as connection to the labour market. In this part, the CoE points out the social dimension and equal opportunities. The funding system should be based on long term contracts, and it should support diversification of the HE system, i.e., to concentrate funding on chosen (excellent) institutions and/or fields. In addition, universities are to diversify their funding streams and strategically ensure their own financial sustainability. Moreover, they should be attentive to efficient and professional spending.

While recognising that the quality of universities is primarily their own responsibility, and that universities should strive to create a culture of quality, it is stated that this is not enough for accountability. For this reason, there is a focus on external quality assurance, and it is recommended that this shift from ex ante to ex post evaluation, and that people from industry be included in the decision making bodies of agencies.

\section{Relationship with the business sector}

The sub-discourse includes the relationship between the two sectors in the teaching function, as well as structurally connecting the two sectors, for example:

...the stronger involvement of enterprises in university boards, research agendas, admission panels, curriculum design, course delivery and QA 
systems can significantly improve universities' teaching, research and innovation (European Commission, 2009).

Regarding teaching, it is proposed that curricula should be directly relevant to the world of work, with the inclusion of employability skills, and that people from industry should cooperate in both curricula development and teaching. Universities are expected to offer career guidance, track graduates and organise alumni, while the system in general should use employment data and projections for planning work and activities. Connection of teaching with the business sector is envisaged for all study cycles, including doctoral education, for which the EU has developed industrial doctorates and principles based on innovative doctoral education.

Cooperation between universities and business is to increase substantially, in the form of structured partnerships and knowledge transfer offices. In addition, universities are expected to professionally manage intellectual property rights and patents and create spin-offs and start-ups.

Universities should be systematically involved in the development of integrated local and regional development plans; they should organise themselves as local knowledge hubs, advance the local economy and attract talent.

\section{Content changes}

The sub-discourse on content changes predicts that curricula changes will include generic competences and employability skills, a view that is recognised by all of the four clusters. The EU thoroughly elaborates the skills for the HE curricula pursuant to the new skills for new jobs initiative. ${ }^{2}$ The EUA cluster similarly denotes generic competences:

...the development of transversal skills and competencies such as communication and languages, ability to mobilise knowledge, problem solving, team work and social processes (EUA, 2001).

Moreover, the competences that are most commonly directly mentioned in the policy documents are entrepreneurship, teamwork and ICT skills, as well as economics and technology.

Additionally, it is recognised that the population ('human capital' in the EU vocabulary) in the knowledge society needs research and technical competences. It is foreseen that the existing workforce will enter HE, and in order for

2 Mother tongue literacy, numeracy, knowledge of foreign languages, science and IT skills. It also covers other skills, such as learning to learn, social and civic competence, initiative-taking, entrepreneurship, cultural awareness and self-expression (http://ec.europa.eu/education/ lifelong-learning-policy/key_en.htm) 
this to happen universities need to make lifelong learning part of their basic mission, as well as making entry and exit points flexible.

In the EU cluster, $\mathrm{STEM}^{3}$ disciplines are favoured, as they are promoted as making an important contribution to the economy.

As mentioned in the introduction, the purpose of the present article is not to demonstrate the discursive differences between the four clusters in concrete terms. To summarise, there are two basic ideations regarding the roles of HEIs, namely the 'traditional' and the 'new. The findings of the present analysis are similar to those of other authors (e.g., Simons, 2007), who have elaborated the difference between the EU ideation and that of the EUA by explaining how the EUA communicates the public dimension of university in line with the critical humanist intelligentsia, as opposed to the economically utilitarian dimension of the EU. Thus European discourses are complex and sometimes include opposing ideations, making policy influence from the international to the national level even more complicated. The following section contains an analysis of how the discourses found in the four clusters of the international policy documents are followed in the Slovenian documents.

\section{Slovenian policy}

The NHEP (strategy for higher education) and the RISS (strategy for research and innovation) are somehow different policies in line with Gornitzka's (2010) finding on policy separation of the two basic functions of the university, i.e., teaching/learning versus research, with possible clashes. The RISS is much more compliant with the international discourses, mainly the EU cluster, while the NHEP also elaborates on other parts of the discursive ideation, namely the 'traditional. However, for the purpose of the present research endeavour, both of the documents are seen as complementary strategies and their common ideation is analysed. The main ideational differences between the documents are pointed out only when necessary.

\section{The presence of Discourse 1}

The NHEP and the RISS share the common title of 'Audacious Slovenia', and a play of words in Slovenian is used trying to bring together the two words 'knowledge' and 'society' in the form of a coined word. Thus the policy documents are immediately terminologically connected to the 'knowledge society'. 
The documents recognise the new circumstances identified in the international discourses, such as global competition, the race for talent, the need for a greater share of people with HE competences, the need for more doctors of science and researchers in the population, and similar. Together, the documents take the common imaginary of the KE for granted, as well as the role of knowledge within it, for example:

Slovenia has to focus on increasing the cohesiveness of society and competitiveness of its economy, while consolidating and restructuring its public finances. In order to achieve this, Slovenia is relying on creativity and knowledge, which are fundamental values and the sources of the country's future wealth (Kolar \& Komljenovič, 2011, p. 101).

\section{New roles of universities and new aims for higher education}

The NHEP emphasises the 'traditional' role of HE and recognises the 'new' one. The RISS is more explicit in connecting the two sectors - universities and the economy. The Slovenian strategies set the economic use of knowledge, knowledge transfer, spin-offs and start-ups as part of the national priorities. However, they do not position universities as actors of the economy, responsible for creating jobs or directly ensuring the economic prosperity of the country. Universities are thus not positioned as 'motors of the economy' or the main responsible actors for it:

Knowledge as it relates to the transfer of knowledge and of technologies is of key importance for the creation of high-tech spin-off enterprises from the PROs [NA: public research organizations] which can exploit the results of the research and development activities. Non-technological transfer of knowledge to society may contribute to its cohesion, health and creativity and an overall higher quality of life (Kolar \& Komljenovič, 2011, p. 115).

Regarding the new aims for HE, the Slovenian policy does not expect universities to directly position Slovenia as a globally competitive country or to make it attractive. It is stated that knowledge is central and important to achieving this goal and that universities contribute as they create knowledge; however, unlike in European policy, it is not stated this is a concrete task of universities.

What the Slovenian policy does define is the attractiveness of universities and the HE system itself. Both of the strategies aim to make Slovenian universities attractive and competitive:

At present, the attraction of our higher education area compared to other countries is extremely low; consequently, a number of immediate national and institutional measures must be adopted to increase the 
internationalisation of the Slovenian higher education area (Kolar \& Komljenovič, 2011, p. 53).

These ideas are balanced with notions of cooperation and the social dimension; in fact, the social dimension is one of the seven main goals of the NHEP.

\section{Supranational policy making}

Slovenia is an initial signatory of the BP from 1999, as well as being an $\mathrm{EU}$ member state. Consequently, it is subject to the international expectations elaborated above - it cooperates in BP structures, in different clusters and peer learning groups organised by the European Commission and in the EU benchmarking exercises, while also preparing national reports for the realisation of the Lisbon Strategy and so on. Either in agreement or not, it cooperates in this new reality. Based on the analysed national strategies, one can assert that it does so with no objections, as both of the documents claim to be prepared in accordance with the Europe 2020 Strategy and other European processes. Moreover, the RISS seems to have been influenced by additional international agencies:

In the autumn of 2010, studies were carried out by the international group of experts under the auspices of the Organisation for Economic Co-operation and Development (OECD) and the European Research Area Committee. These studies examined the Slovenian research and innovation environment and public policies in these areas, and subsequently provided recommendations for their optimisation. The results and recommendations of these studies were taken into consideration during the preparation of the Strategy (Kolar \& Komljenovič, 2011, p. 102).

\section{The presence of Discourse 2}

\section{Managerial university}

The group of ideas tackling universities' governance in the international sub-discourse is mirrored in the Slovenian policy to a very small extent. The Slovenian policy does not predict that universities will professionalise management, nor does it foresee leadership training or introducing leadership for managers from outside academia. Furthermore, there are no proposals that business should advise on the management structures of universities. The policy only predicts an institutional strategy setting and better cooperation between disciplines and faculties within the universities.

The national policy is more in line with the second group of ideas in this sub-discourse. Thus knowledge transfer to business is promoted, as well 
as spin-offs and star-ups and an entrepreneurial culture. This is much more evident in the RISS than in the NHEP.

A part of the third group of ideas can be found in the Slovenian strategies as well. It is recognised that Slovenian universities already enjoy a high level of autonomy, and it is predicted that this will even increase in some parts of human resource management, by way of exempting academic and research staff from civil service status. Overregulation is mentioned, and it is stated that internal management will be left completely to universities, while, on the other hand, better responsiveness to society and higher accountability is envisaged. Thus the state will indeed focus on the strategic orientation of the system. Autonomy is used cognitively and normatively, i.e., as a value safeguarding academic freedom and as an instrument for responsiveness to societal needs and increased competitiveness.

The idea of diversification is present, partly in line with the international discourse and partly in contradiction to it. There is compliance for the differentiation of universities' profiles regarding the identification of institutional strengths, the focus on different student groups, teaching and research priorities. In addition, the RISS elaborates on 'smart specialisation' developed by a bottom-up approach completely compliant with the EU cluster. On the other hand, there is a discrepancy regarding the differentiation of the main mission of universities - research. The documents recognise that the main aim of universities is to produce knowledge, and fundamental research is prioritised especially. All universities are expected to have this profile, which is in contradiction to the European discourse. Other HEIs are expected to focus on the teaching role as the main priority, as well as connection to the profession and vocation. In this sense, the Slovenian policy is fully in line with the EUA, BP and CoE clusters, but only partly conforms to the EU cluster.

Funding is predicted to increase both for $\mathrm{HE}$ and research, but there is again an important difference with regard to the international discourse. Public funding, which is already comparable to the $\mathrm{EU}^{4}$ or even higher, is predicted to increase substantially mainly from the public source, and student fees will to be introduced. The elements of international discourse that are present are long term contracts between the state and universities, specifying the goals to be achieved by universities. However, the share of funding for HE based on outcomes as opposed to the fixed share is predicted to be rather small in comparison to the expectation from the international discourse (only $3 \%$ of funds).

4 According to EUROSTAT data, total public expenditure on education as \% of GDP at tertiary level of education (ISCED 5-6) was $1.38 \%$ in 2009 , while the EU 27 average was $1.22 \%$. 
The group of ideas on quality assurance is in line with the international discourse, as the quality culture at universities and internal quality assurance are emphasised. With regard to external quality assurance, a system is predicted that is completely in line with the international discourse, i.e., implementing the ESG ${ }^{5}$, ex post evaluation, non-academic stakeholders in the governance of the agency, public and transparent information, and similar ideas.

\section{Relationship with the business sector}

The teaching function part of this international sub-discourse is partly compatible with the Slovenian policy. The latter expects universities to be attentive to employers' needs regarding the curricula; however, this is seen as in important part of academic autonomy. Thus direct employability skills are not mentioned for universities, while such an expectation is created for professional HEIs.

Career guidance, alumni and diploma supplement are present in the national policy.

\section{Content changes}

The Slovenian policy mentions the qualification framework, as well as the required generic competences offered in the curricula:

All study programmes must ensure that knowledge and skills are obtained in accordance with a national qualification framework and key competences, including innovation, critical thinking, communication in the mother tongue, cultural consciousness and expression, ability to operate in the international environment and information literacy, are developed (Kolar \& Komljenovič, 2011, p. 15).

Opportunities will be created to gain entrepreneurial skills and entrepreneurial culture among students, as well as for the simple establishment of enterprises (Kolar \& Komljenovič, 2011, p. 116).

As mentioned above, the direct relevance of curricula to the labour market is predicted for professional HEIs but not for universities, thus making the national policy partly compliant with the international discourse. The situation is similar regarding STEM disciplines, as they are favoured in the RISS for economic purposes, but not in the NHEP.

There are some original issues in the Slovenian policy of 2011 that are not presented in the present paper, as the aim of the article is to identify the discourses in the international policy and only then show their presence in the Slovenian case.

5 Standards and Guidelines for Quality Assurance in the European Higher Education Area. 


\section{Conclusion}

While there is compliance with international discourses to a significant extent, the Slovenian HE policy still seems to encompass the 'traditional' idea of a university to an important degree. It seems that the new conceptualisation of universities as institutions with integrated economic development as a core function, which has been increasingly present in European policy in the past decade, does not fit comfortably in the Slovenian context. HEIs are not expected to be 'motors of the economy' or to be directly responsible for Slovenian global competitiveness, although it is recognised that they have an important role in the $\mathrm{KE}$ as institutions creating and transmitting knowledge. In addition, there is strong motivation to use knowledge in the economy, thus contributing to the creation of jobs. However, there are no direct expectations for HEIs to be responsible for the state of the economy.

The other important difference between the international and national discourses is in the concept of the managerial university. The Slovenian strategies do not predict that universities will professionalise in terms of turning into 'business-like' organisations, as would be expected in line with international trends (Felt, 2001). Furthermore, there is no expectation that they diversify funding streams in the direction of privatisation. In addition, autonomy is not reduced solely to the managerial concept, as it emphasises the normative ideational part, and even uses the cognitive part for non-economic purposes such as academic freedom.

Even though there is a multitude of ideas, concepts and measures in the Slovenian policy that mirror international discourses, the identified differences are important conceptual contrasts between the national and international policy.

It is possible to assert that the 'new' goals and roles of universities are defined in the European and Slovenian policy, and that there are latent clashing ideas between the 'traditional' and the 'new' conceptualisation of universities. Gornitzka (2010) explains that the fundamental change can be expected when goals and interests from one sphere invade the other, elaborating that for the changes of the societal sectors to occur, the "interaction between the sectors that are built on different principles is a fundamental dynamic of change" p. 537. Less dramatic changes in the HE sector can be seen when 'only' the "marketlike solutions are imported to adjust the governance mechanisms in the academic sphere without changing the overall policy paradigm”, p. 537. The finding of the present research is that at the European level substantial interactions between sectors of $\mathrm{HE}$ and the economy are foreseen and encouraged. This means that not only the 'market-like solutions' for HE are predicted, but the HE goals 
and interests seem to change as the business sector is invited to interact with HE. This is also the case in Slovenian policy, even if it receives less emphasis and even if the new conceptualisation found in European policy is not picked up completely. Thus, based on findings from the analysis, important changes in the conceptualisation of $\mathrm{HE}$ at the European level, and even more so at the Slovenian level, can be expected in the future.

\section{References}

Bladh, A. (2007). Institutional Autonomy With Increasing Dependency on Outside Actors. Higher Education Policy, 20(3), 243-259.

Blasi, P. (2002). The idea of Europe through the history of universities: the European dimension as university heritage in the past, today and in the future. In N. Sanz, \& S. Bergan (Eds.), The Heritage of European Universities (pp. 103-110). Strasbourg: Council of Europe Publishing.

Boer, H. d., Enders, J., \& Jongbloed, B. (2009). Market Governance in Higher Education. In B. M. Kehm, J. Huisman, \& S. Bjørn (Eds.), The European Higher Education Area: Perspectives on a Moving Target (pp. 61-78). Rotterdam: Sense publishers.

Corbett, A. (2011). Ping Pong: competing leadership for reform in EU higher education 1998-2006. European Journal of Education, 46(1), 36-53.

Corbett, A. (2012). Principles, Problems, Politics....What Does the Historical Record of EU Cooperation in Higher Education Tell the EHEA Generation? In A. Curaj, P. Scott, L. Vlasceanu, \& L. Wilson (Eds.), European higher education at the crossroads: between the Bologna process and national reforms (pp. 39-58). Dordrecht: Springer.

Council of Europe. (2007). Recommendation CM/Rec(2007)6 of the Committee of Ministers to member states on the public responsibility for higher education and research. Strasbourg: Council of Europe.

Council of Europe. (2012). Recommendation CM/Rec(2012)7 of the Committee of Ministers to member States on the responsibility of public authorities for academic freedom and institutional autonomy.

Strasbourg: Council of Europe.

Council of the European Union. (2007). Council Resolution on modernising universities for Europe's competitiveness in a global knowledge economy. Brussels: Council of the European Union.

Etzkowitz, H. (1998). The norms of entrepreneurial science: cognitive effects of the new universityindustry linkages. Research Policy, $27(8), 823-833$.

EUA. (2001). The Salamanca Declaration, Shaping the European Higher Education Area. Genève European University Association. Retrieved from http://www.eua.be/eua/jsp/en/upload/

SALAMANCA_final.1069342668187.pdf

EUA. (2003). The Graz Declaration, Forward from Berlin: the Role of Universities to 2010 and Beyond. Brussels: European University Association. Retrieved from http://www.eua.be/eua/jsp/en/upload/ GrazDecENG.1066743764824.pdf 
EUA. (2009). EUA Prague Declaration, European Universities - Looking Forward with Confidence Brussels. European University Association. Retrieved from http://www.eua.be/eua-work-and-policyarea/eua-policy-position-and-declarations.aspx

European Commission. (2001). Communication from the Commission to the European Parliament and the Council on Strengthening Cooperation with third Countries in the Field of Higher Education. Brussels: European Commission.

European Commission. (2003). Communication from the Commission. The role of the universities in the Europe of knowledge. Brussels: European Commission.

European Commission. (2005). Communication from the Commission. Mobilising the brainpower of Europe: enabling universities to make their full contribution to the Lisbon Strategy. Brussels: European Commission.

European Commission. (2006). Communication from the Commission to the Council and the European Parliament. Delivering on the Modernisation Agenda for Universities: Education, Research and Innovation. Brussels: European Commission.

European Commission. (2009). Communication from the Commission to the European Parliament, the Council, the European Economic and Social Committee and the Committee of the Regions. A new partnership for the modernisation of universities: the EU Forum for University Business Dialogue. Brussels: European Commission.

Fairclough, N., \& Wodak, R. (2008). The Bologna Process and the knowledge-based economy: a critical discourse analysis approach. In B. Jessop, N. Fairclough, \& R. Wodak (Eds.), Education and the knowledge based economy in Europe (pp. 109-126). Rotterdam: Sense.

Felt, U. (2001). University autonomy in Europe: changing paradigms in higher education policy: special case studies: decision-making structures and human resources management in Finland, France, Greece, Hungary, Italy, the Netherlands, Spain and the United Kingdom. Vienna: University of Vienna. Felt, U. (2005). University Autonomy in the European Context: Revisiting the Research - Teaching Nexus in a Post-Humboldtian Environment Managing University Autonomy, University autonomy and the institutional balancing of teaching and research. Bologna: Bononia University Press.

Gornitzka, Å. (2010). Bologna in Context: a horizontal perspective on the dynamics of governance sites for a Europe of Knowledge. European Journal of Education, 45, 535-548.

Gumport, P. J. (2000). Academic restructuring: Organizational change and institutional imperatives. Higher Education, 39, 67-91.

Jessop, B. (2008). The cultural political economy of the knowledge-based economy and its implications for higher education. In B. Jessop, N. Fairclough, \& R. Wodak (Eds.), Education and the knowledge based economy in Europe (pp. 13-39). Rotterdam: Sense.

Kolar, J., \& Komljenovič, J. (2011). Resolution on the National higher education programme 2011-2020. Resolution on the Research and innovation strategy of Slovenia 2011-2020 : [audacious Slovenia].

Ljubljana: Ministry of Higher Education, Science and Technology.

Maassen, P., \& Stensaker, B. (2011). The knowledge triangle, European higher education policy logics and policy implications. Higher Education, 61(6), 757-769. doi: 10.1007/s10734-010-9360-4 
Olsen, J. P. (2009). Democratic Government, Institutional Autonomy and the Dynamics of Change. ARENA Working Paper, No 1. Retrieved from http://www.arena.uio.no Olssen, M., \& Peters, M. A. (2005). Neoliberalism, higher education and the knowledge economy: from the free market to knowledge capitalism. Journal of Education Policy, 20(3), 313-345.

Robertson, S. (2008). Embracing the global: crisis and the creation of a new semiotic order to secure Europe's knowledge-based economy. In B. Jessop, N. Fairclough, \& R. Wodak (Eds.), Education and the knowledge based economy in Europe (pp. 89-108). Rotterdam: Sense.

Schmidt, V. A. (2010). Taking ideas and discourse seriously: explaining change through discursive institutionalismas the fourth 'new institutionalism'. European Political Science Review, 2(1), 1-25. Simons, M. (2007). The 'Renaissance of the University' in the European knowledge society: An exploration of principled and governmental approaches. Studies in Philosophy and Education, 26(5), 433-447.

Sorbonne Declaration. (1998). Joint declaration on harmonisation of the architecture of the European higher education system. Paris, the Sorbonne. Retrieved from http://www.bologna-berlin2oo3.de/pdf/ Sorbonne_declaration.pdf

Välimaa, J., \& Hoffman, D. (2007). Higher Education and Knowledge Society Discourse Higher Education Looking Forward: Themes on the Changing Relationship between Higher Education and Society. European Science Foundation.

Weert, E. d., \& Vucht Tijssen, L. v. (1999). Academic staff between threat and opportunity: Changing employment and conditions of service. In B. Jongbloed, P. Maassen, \& G. Neave (Eds.), From the Eye of the Storm: Higher Education's Changing Institution. Dodrecht: Kluwer Academic Publishers. Wende, M. v. d., Beerkens, E., \& Teichler, U. (1999). Internationalisation as a cause for innovation in higher education: A comparison between European cooperation and the Dutch cross - border cooperation programme. In B. Jongbloed, P. Maassen, \& G. Neave (Eds.), From the eye of the storm : higher education's changing institution. Dordrecht ; London: Kluwer Academic Publishers.

\section{Biographical note}

JANJA KomlJenovič is an assistant researcher at the Centre for Educational Policy Studies, University of Ljubljana. She has been working in the field of higher education for more than a decade beginning as a student representative in $\mathbf{2 0 0 2}$ when she was involved in national and European higher education policy making, especially in the Bologna process and quality assurance. In 2007 she worked for European University Association and between 2009 and 2011 she was advisor to the Slovenian Minister of higher education, science and technology; since 2011 she works at the University of Ljubljana. Her research interests are mainly the roles of universities in contemporary societies, university governance and autonomy and changing circumstances for higher education. 